\title{
Molecular Cloning and Characterization of a Candidate Plant Growth-Related and Time-Keeping Constitutive Cell Surface Hydroquinone (NADH) Oxidase (ENOX1) from Arabidopsis lyrata
}

\author{
Xiaoyu Tang, Laura M. C. Ades, Dorothy M. Morré, D. James Morré* \\ MorNuCo, Inc., Purdue Research Park, West Lafayette, IN, USA \\ Email: ${ }^{*}$ j morre@yahoo.com
}

Received 22 December 2014; accepted 24 January 2015; published 2 February 2015

Copyright (C 2015 by authors and Scientific Research Publishing Inc.

This work is licensed under the Creative Commons Attribution International License (CC BY).

http://creativecommons.org/licenses/by/4.0/

(c) (i) Open Access

\section{Abstract}

ENOX (ECTO-NOX) proteins are proteins of the external surface of the plasma membrane that catalyze oxidation of both NADH and hydroquinones as well as carry out protein disulfide-thiol interchange. They exhibit both prion-like and time-keeping (clock) properties. The oxidative and interchange activities alternate to generate a regular period of $24 \mathrm{~min}$ in length. Here we report the cloning, expression, and characterization of a plant candidate constitutive ENOX (CNOX or ENOX1) protein from Arabidopsis lyrata. The gene encoding the 335 (165) amino acid protein is found in accession XP-002882467. Functional motifs characteristics of ENOX proteins previously identified by site-directed mutagenesis and present in the candidate ENOX1 protein from plants include adenine nucleotide and copper binding motifs along with essential cysteines. However, the drug binding motif (EEMTE) sequence of human ENOX2 is absent. The activities of the recombinant protein expressed in E. coli were unaffected by capsaicin, EGCg, and other ENOX2-inhibiting substances. Periodic oxidative activity was exhibited both with NAD(P)H and reduced coenzyme $Q$ as substrate. Bound copper was necessary for activity and activity was inhibited by the ENOX1specific inhibitor simalikalactone $D$. Addition of melatonin phased the 24-min period such that the next complete period began $24 \mathrm{~min}$ after the melatonin addition as appeared to be characteristic of ENOX1 activities in general. Periodic protein disulfide-thiol interchange activity also was demonstrated along with the 2 oxidative plus 3 interchange activity pattern characteristics of the 24min ENOX1 protein period. Concentrated solutions of the purified plant ENOX1 protein formed insoluble aggregates, devoid of enzymatic activity, resembling amyloid. Activity was restored to

\footnotetext{
"Corresponding author.
} 
aggregate preparations by isoelectric focusing.

\title{
Keywords
}

\author{
ENOX1, ECTO-NOX Proteins, Plant Growth, Hydroquinone (NADH) Oxidation, Plasma Membrane \\ Electron Transport, Arabadopsis lyrata
}

\section{Introduction}

One or more hormone-responsive external plasma membrane hydroquinone oxidases capable of catalyzing protein disulfide interchange and that oxidize $\mathrm{NAD}(\mathrm{P}) \mathrm{H}$ as an alternate substrate (External NADH oxidase = ENOX) have been exhibited by all animal and plant species, thus far investigated, as well as by yeast [1]-[3]. Based on activity characteristics, three related ENOX proteins have emerged. One (CNOX or ENOX1) is both constitutive and widely distributed [4]. A second ENOX activity designated tNOX or ENOX2 is tumor or cancer-associated [5] [6]. ENOX2 proteins are inhibited by a series of quinone site inhibitors all with anticancer activity including the vanilloid capsaicin [7] [8], the antitumor sulfonylurea LY181984 [9] [10], the isoflavone phenoxodiol [11] and the quassinoid glaucarubolone [12] whereas ENOX1 proteins are resistant [11] to these substances but inhibited specifically by the quassinoid simalikalactone D which has no effect on ENOX2 activity [13]. Shed forms of both activities are found in culture media conditioned by the growth of mammalian [10] or plant cells. A 33.5-kDa protein with capsaicin-inhibited NADH oxidase activity was purified from spent media of cultured HeLa cells [14] and from sera of cancer patients [5]. The NADH oxidase activities from sera of healthy volunteers or spent media of non-cancer cells were identified as ENOX1 [15]. A third group of proteins with ENOX-like activity designated arNOX/ENOX3 [16] is age-related [17] and evident only in aged individuals, late passage cultured cells, or senescing [19] short-lived plant parts [17] [18].

The ENOX1 and ENOX 2 proteins function in the enlargement phase of cell growth [19]-[21]. When their activity is inhibited, cells are unable to enlarge [2] [7] [13] [22]. Cancer cells unable to enlarge to a size sufficient to allow division following inhibition of ENOX2 undergo apoptosis. Arabidopsis seedlings treated with the quassinoid ENOX1 inhibitor simalikalactone D ceased growth until the drug was metabolized but did not die [13].

A distinguishing characteristic of ENOX proteins that permits their unequivocal identification is that the proteins exhibit two activities that alternate [1]-[3]. The first activity is that of a hydroquinone oxidase (NADH serves as an alternate substrate for this activity) [23]. The second is that of a protein disulfide-thiol interchange measured either from the restoration of activity to inactive (scrambled) RNase [24] or from the cleavage of dithiodipyridine substrates [25]. Each activity generates a distinct oscillatory activity with a period length of 24 min for ENOX1. The strictly periodic activity of the NOX proteins (ENOX1 and ENOX2 as well as arNOX) distinguishes their activity from all other oxidase or protein disulfide isomerase forms [6] and imparts to the ENOX1 protein a potential role as an ultradian (with period lengths of less than $24 \mathrm{~h}$ ) oscillator of the cellular biological clock [26].

In a previous report [15], purification of a protease-resistant protein fragment with drug-resistant ENOX1 activity and a period length of 24 min from human serum protein, was described. The protein fragment was blocked to direct sequencing and was resistant to further protease digestion. Polyclonal antibodies raised to the fragment partially blocked total NOX activity of human sera from the surface of human non-cancer cells. They did not react with recombinant ENOX2 or with molecular species identified as ENOX2 from sera of cancer patients or from cancer cell lines grown in culture. The human ENOX1 was the first candidate ENOX1 to be cloned and expressed as a recombinant protein [4].

ENOX proteins lack iron or iron-sulfur clusters but still reduce oxygen. The previously cloned and sequenced ENOX2 protein contains a copper site conserved with the copper site of the enzyme $\mathrm{Mg}^{2+}$ superoxide dismutase [6]. Site-directed mutagenesis of this copper site resulted in the loss of enzymatic activity when the mutant protein was expressed in Escherichia coli [6] [27]. These findings were extended to the candidate plant ENOX1 protein with the discovery of a second copper site also required for activity [4]. These findings raise the possibility that the concerted four electron transfers required to reduce molecular oxygen to water are carried out by 
dimers of the dicopper-containing ENOX monomers. In this report, a candidate plant ENOX1 protein with functional motifs consistent with this activity model was cloned and characterized from Arabidopsis lyrata.

\section{Methods}

\subsection{Search for Candidate Constitutive ENOX1 (ENOX1) from Plants}

Protein BLAST (Basic Local Alignment Search Tool) with either ENOX1 or ENOX2 sequences as a query was used for similarity searches in different databases (non-redundant protein sequences, UniProt, EST, and others) [28] with no plant proteins having significant similarity being found. However, sequence of a cloned ENOX1 from Saccharomyces cerevisiae [29] did reveal significant homology. The homologous protein from Arabidopsis lyrata was selected for evaluation as a candidate for the constitutive ENOX1 from plants.

\subsection{Plasmids Construction}

Plasmids carrying the Arabidopsis ENOX1 (M458 to V580 of hypothetical protein RALYDRAFT_477943 [Arabidopsis lyrata aubsp. Lyrata] XP_002882467) sequence were prepared by inserting the pET11a vector (between NheI and BamHI sites) within the Arabidopsis ENOX1 sequence. The Arabidopsis ENOX1 sequence was synthesized by GenScript USA Inc. (Piscataway, NJ). DNA sequences of the ligation products (pET11aAraENOX1) were confirmed by DNA sequencing.

\subsection{Expression of Recombinant Arabidopsis ENOX1}

The pET11a-AraENOX1 was transformed to BL21 (DE3) competent cells. A single colony was picked and inoculated into the $5 \mathrm{ml} \mathrm{LB}+$ ampicillin (LB/AMP) medium. The overnight culture $(1 \mathrm{ml})$ was diluted into $100 \mathrm{ml}$ LB/AMP media (1:100 dilution). The cells were grown with vigorous shaking ( $250 \mathrm{rpm}$ ) at $37^{\circ} \mathrm{C}$ to an $\mathrm{OD}_{600}$ of 0.4 - 0.6 and IPTG $(0.5 \mathrm{mM})$ was added for induction. Cultures were collected after $5 \mathrm{~h}$ incubation with shaking (250 rpm) at $37^{\circ} \mathrm{C}$.

Cells were centrifuged at $5000 \mathrm{~g}$ for $6 \mathrm{~min}$. Pellets were then resuspended in $20 \mathrm{mM}$ Tris-HCl, pH 8.0, containing $0.5 \mathrm{mM}$ PMSF, $1 \mathrm{mM}$ benzamidine and $1 \mathrm{mM}$ 6-aminocaproic and lysed by three passages through a French pressure cell (SLM Aminco) at 20,000 psi. Expression of the recombinant Arabidopsis ENOX1 of about $14 \mathrm{kDa}$ was confirmed by SDS-PAGE with silver staining. Transformed cells were stored at $-80^{\circ} \mathrm{C}$ in a standard glycerol stock solution. The Arabidopsis ENOX1 proteins were further purified on Criterion IEF gels (Bio-Rad, Hercules, CA). The IEF gel was cut into seven equal segments. The $\mathrm{pH}$ represented by each slice was based on IEF standards (Bio-Rad). The slices were soaked in $15 \mathrm{mM}$ Tris-Mes buffer, $\mathrm{pH} 7$, at $4^{\circ} \mathrm{C}$ for overnight with shaking. The gel-free extracts were assayed for ENOX1 activity.

\subsection{Protein Determination}

Protein concentrations were determined by the bicinchoninic acid (BCA) method [30] (BCA Protein Assay Kit, Thermo Scientific, Rockford, IL, USA) with bovine serum albumin as the standard.

\subsection{Enzyme Activity Assays}

Oxidation of NADH was determined spectrophotometrically from the disappearance of NADH measured at 340 $\mathrm{nm}$ in a reaction mixture containing $25 \mathrm{mM}$ Tris-MES (pH 7.2), $100 \mu \mathrm{M} \mathrm{GSH}, 1 \mathrm{mM} \mathrm{KCN}$ to inhibit mitochondrial oxidase activity, $150 \mu \mathrm{M} \mathrm{NADH}$ and the enzyme at $37^{\circ} \mathrm{C}$ with temperature control $\left( \pm 0.5^{\circ} \mathrm{C}\right)$ and stirring. Prior to assay, $1 \mu \mathrm{M}$ reduced glutathione was added to reduce the protein in the presence of substrate. After 10 min, $0.03 \%$ hydrogen peroxide was added to reoxidize the protein under renaturing conditions and in the presence of substrate to start the reaction. Activities were measured using paired Hitachi U3210 or paired SLM Aminco 2000 spectrophotometers both with continuous recording. Assays were for $1 \mathrm{~min}$ and were repeated on the same sample at intervals of $1.5 \mathrm{~min}$ for the times indicated. An extinction coefficient of $6.22 \mathrm{~cm}^{-1} \mathrm{mM}^{-1}$ was used to determine specific activity.

Oxidation of reduced coenzyme $\mathrm{Q}_{10}\left(\mathrm{CoQ}_{10} \mathrm{H}_{2}\right)$ was measured as the disappearance of $\mathrm{CoQ}_{10} \mathrm{H}_{2}$ at both 290 $\mathrm{nM}$ and $410 \mathrm{nM}$ [23]. The reaction was started with the addition of $40 \mu \mathrm{l}$ of $5 \mathrm{mM} \mathrm{Q}_{10} \mathrm{H}_{2}$ (Tischcon Corp., Westbury, NY). An extinction coefficient of $0.805 \mathrm{mM}^{-1} \mathrm{~cm}^{-1}$ was used to calculate the rate of $\mathrm{Q}_{10} \mathrm{H}_{2}$ oxidation. 
Protein disulfide-thiol interchange was determined spectrophotometrically from the increase in absorbance at $340 \mathrm{~nm}$ resulting from the cleavage of dithiodipyridine (DTDP) [25]. DTDP cleavage was buffered $50 \mathrm{mM}$ Tris-MES, pH 7. The assay was preincubated ( $1 \mathrm{~h}$ at room temperature) with $0.5 \mu$ moles DTDP in $5 \mu \mathrm{l}$ of dimethyl sulfoxide (DMSO) to react with endogenous reductants present with the plasma membranes. After 10 min, a further $3.5 \mu$ moles DTDP were added in $35 \mu$ DMSO to start the reaction. The final reaction volume was $2.5 \mathrm{ml}$. The reaction was monitored from the increase in absorbance at $340 \mathrm{~nm}$. Specific activities were calculated using a milimolar absorption coefficient of 6.21 .

\subsection{Removal of Copper (II) from ENOX1}

IEF purified ENOX1 was concentrated to $0.7 \mathrm{mg} / \mathrm{ml}$ by using a Centricon concentrator (Millipore Corporation, Danvers, MA) fitted with a 10,000 nominal molecular weight limit ultracel YM membrane. Samples (50 $\mu$ l) were combined with $1 \mu$ l of trifluoroacetic acid (TFA) in the presence or absence of $15 \mu 10 \mathrm{mM}$ bathocuproine. After $2 \mathrm{~h}$ of incubation at room temperature, the samples were dialyzed (Spectra/Pro Dialysis membrane, molecular weight cut-off 6000 - 8000, Spectrum Laboratories (Rancho Dominquez, CA) against 20 mM Tris-HCl, $\mathrm{pH} 8$, at $4^{\circ} \mathrm{C}$ overnight.

\subsection{Site-Directed Mutagenesis}

Amino acids indicated were replaced by alanines by site directed mutagenesis according to Braman et al. [31]. Numbered amino acids and nucleotide positions of splice variant products refer to numbers assigned to amino acids of the full length transcript.

\subsection{Statistical Analyses}

Means and standard deviations were analyzed for statistical significance using a two-tailed test.

\section{Results}

The identification of the candidate plant the ENOX1 from Arabidopsis lyrata was based on a homology (BLAST) search by comparison with the ENOX1 (YML117W) from Saccharomyces cerevisiae [29]. The 14 kDa amino acid sequence selected (Figure 1) had 37\% identity and 58\% similarity between amino acids 84 and 126 of XP002882467 from Arabidopsis and amino acids 932-968 of EDN64277 (YML117W) from yeast.

Potential functional motifs within the $14 \mathrm{kDa}$ transcript included a potential $\mathrm{NADH}$ binding site at G570XGXXL which aligned with G958XGXXV in YML117W. Potential protein disulfide sites were located at M458XXXXCC and M527XXXXXXC along with C534. Potential copper sites were at H466PY, Y531LY (which over laps M527XXXXXXC) and Y479XXXXH.

Expression of the recombinant Arabidopsis ENOX1 with a molecular weight of about $14 \mathrm{kDa}$ was confirmed by SDS-PAGE with silver staining (Figure 2).

\subsection{Protein Characterization}

A continuous trace of an IEF-purified preparation of the recombinant Arabidopsis ENOX1 protein illustrates the characteristic oscillatory activity (Figure 3). Intervals of rapid activity (arrows) were interspersed with intervals of less activity. The period length was $24 \mathrm{~min}$. No oscillations were observed with NADH alone or with the plant ENOX1 in the absence of NADH.

For more detailed evaluations, rates averaged over 1 min every 1.5 min with recombinant plant ENOX1 expressed in E. coli exhibited more clearly the oscillatory pattern of oxidation of exogenously supplied NADH characteristic of ENOX1 proteins (Figure 4). The repeating pattern was that of five maxima, two of which were separated by six min (arrows) and the remainder separated by $4.5 \mathrm{~min}[6+(4 \times 4.5)=24$ min]. As is characteristic of ENOX1 proteins from other sources, the oscillatory pattern could be phased by the addition of $1 \mu \mathrm{M}$ melatonin (Figure 5). A new maximum was observed exactly 24 min after melatonin addition and continued thereafter as phased by the melatonin addition.

As is characteristic of ENOX proteins in general, the proteins also exhibited protein disulfide-thiol interchange (protein disulfide isomerase) activity illustrated by the time-dependent cleavage of a dithiodipyridyl sub- 
a. NCBI Reference Sequence: XP_002882467.1
1 MARNSNSDEA FSSEEEEERV KDNEEEDEEE LEAVARSSGS DDDEVVAADE SPVSDGEAAP
61 VEDDYEDEED EEKAEISKRE KARLKEMQKL KKQKIQEMLE SQNASIDADM NNKGKGRLKY 121 LLQQTELFAH FAKGDASSSQ KKAKGRGRHA SKITEEEEDE EYLKEEEDGL TGSGNTRLLT 181 QPSCIQGKMR DYQLAGLNWL IRLYENGING ILADEMGLGK TLQTISLLAY LHEYRGINGP 241 HMVVAPKSTL GNWMNEIRRF CPVLRAVKFL GNPEERRHIR DDLLVAGKFD ICVTSFEMAI 301 KEKTALRRFS WRYIIIDEAH RIKNENSLLS KTMRLFSTNY RLLITGTPLQ NNLHELWALL 361 NFLLPEIFSS AETFDEWFQI SGENDQQEVV QQLHKVLRPF LLRRLKSDVE KGLPPKKETI 421 LKVGMSQMQK QYYKALLQKD LEAVNAGGER KRLLNIAMQL RKCCNHPYLF QGAEPGPPYT 481 TGDHLITNAG KMVLLDKLLP KLKERDSRVL IFSQMTRLLD ILEDYLMYRG YLYCRIDGNT 541 GGDERDASIE AYNKPGSEKF VFLLSTRAGG LGINLATADV VILYDSDWNP QVDLQAQDRA 601 HRIGQKKEVQ VFRFCTESAI EEKVIERAYK KLALDALVIQ QGRLAEQKTV NKDELLQMVR 661 YGAEMVFSSK DSTITDEDID RIIAKGEEAT AELDAKMKKF TEDAIQFKMD DSADFYDFDD 721 DNKDENKLDF KKIVSDNWND PPKRERKRNY SESEYFKQTL RQGAPAKPKE PRIPRMPQLH 781 DFQFFNIQRL TELYEKEVRY LMQTHQKNQL KDTIDVEEPE GGDPLTAEEV EEKELLLEEG 841 FSTWSRRDFN TFLRACEKYG RNDIKSIASE MEGKTEEEVE RYAKVFKERY KELNDYDRII 901 KNIERGEARI SRKDEIMKAI GKKLDRYRNP WLELKIQYGQ NKGKLYNEEC DRFMICMIHK 961 LGYGNWDELK AAFRTSPLFR FDWFVKSRTS QELARRCDTL IRLIEKENQE FDERERQARK 1021 EKKLAKSATP SKRPLGRQAS ESPSSTKKRK HLSMR

\section{b. Alignment of YML117W and Arabidopsis ENOX1}



Figure 1. Alignment of Saccharomyces cerevisiae YML117W and Arabidopsis ENOX1. Sequence 1 is the recombinant Arabidopsis ENOX1. Sequence 2 is the YML117W. There is 37\% (16/43) identity and 58\% (25/43) similarity between recombinant Arabidopsis ENOX1 amino acids 84 to 126 and YML117W amino acids 932-968.

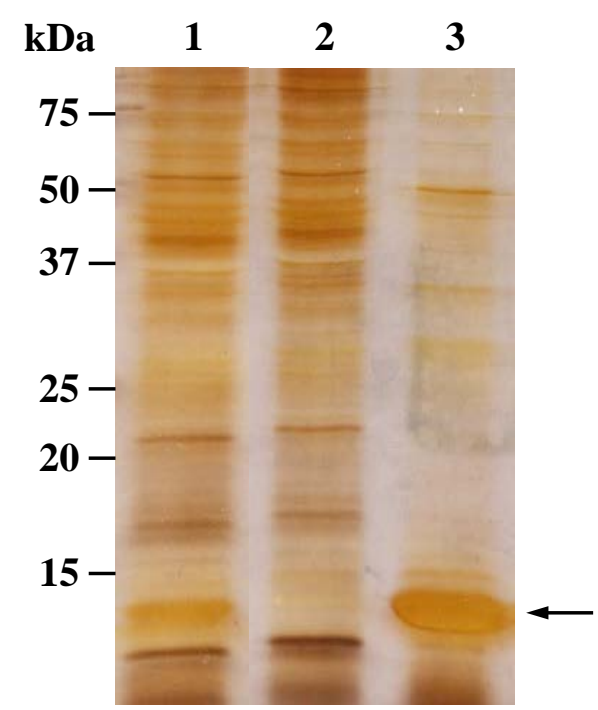

Figure 2. Expression of $14 \mathrm{kD}$ recombinant Arabidopsis ENOX1 shown on 15\% SDS-PAGE with silver staining. Lanes 1 and 2: whole cells of pET11a-AraENOX1 transformed E. coli $(2 \mu \mathrm{l})$; lanes 3 and 4: supernatant of French pressed pET11aAraENOX1 transformed E. coli $(2 \mu \mathrm{l})$; lanes 5 and 6: pellet of French pressed pET11a-AraENOX1 transformed E. coli $(2 \mu \mathrm{l})$. The expressed recombinant Arabidopsis ENOX1 was found in the pellet of French pressed E. coli. 




Figure 3. Continuous trace showing the decrease in $\mathrm{A}_{340}$ as a measure of consumption of NADH over 12 min for a fraction of IEF purified Arabidopsis ENOX1. The assay conditions were as described ([24], Materials and Methods) except that the NADH concentration was 0.75 $\mathrm{mM}$ and the data were collected automatically and stored using a SPECTRA max 340PC microplate reader. The mixture contained ca. $20 \mu \mathrm{g}$ ENOX1 in a total volume of $200 \mu \mathrm{l}$.

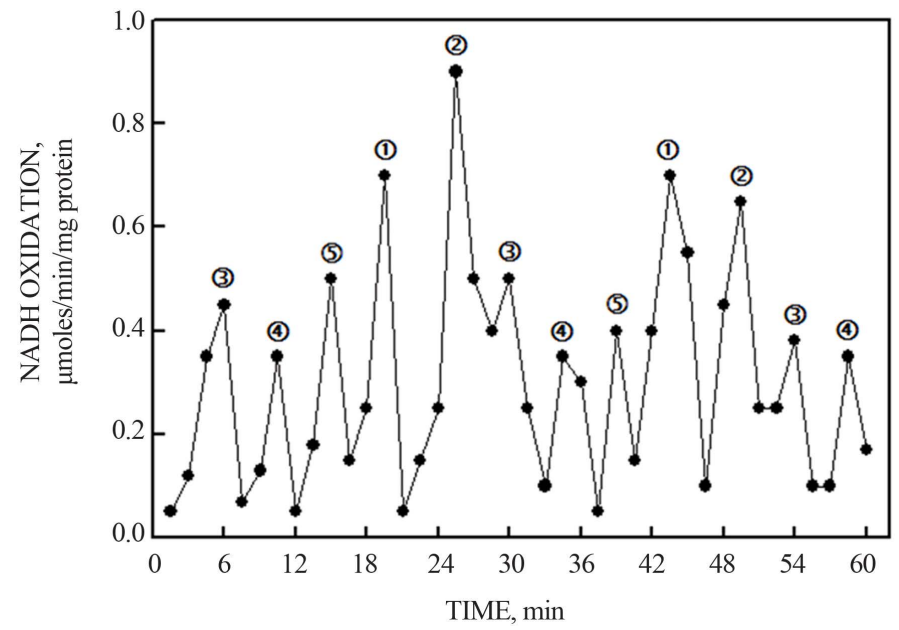

Figure 4. NADH oxidase activity of IEF purified recombinant ENOX1 of Arabidopsis. Illustrated is the oscillatory pattern of 5 maxima. The major maxima separated by $6 \mathrm{~min}$, are labeled (and (2). The three minor maxima that follow are separated from the major maxima and each other by $4.5 \mathrm{~min}$ creating the $24 \mathrm{~min}$ period [ $6+$ $(4.5 \times 4)=24]$.

strate (Figure 6). An oscillatory pattern similar to that for NADH oxidation was observed with a period length of 24 min (arrows). As reported previously [2], the principal maxima of the two activities, NADH oxidation and protein disulfide interchange, alternated.

The recombinant ENOX1 oxidizes reduced coenzyme Q in a standard assay (Figure 7) with activity measured either at $\mathrm{A}_{410}$ (Figure 7(upper)) or at $\mathrm{A}_{290}$ (Figure 7(lower)). As with NADH oxidation (Figure 4) and dithiodipyri-dine cleavage (Figure 6), the characteristic pattern of oscillations with a 24 min period was reproduced (Figure 7). Hydroquinones of the plasma membrane (reduced coenzyme Q for animals/reduced coenzyme Q or phylloquinone for plants) are the physiological substrates for ENOX proteins. 




Figure 5. The NADH oxidase activity of IEF-purified recombinant ENOX1 of Arabidopsis and response to $1 \mu \mathrm{M}$ melatonin. After addition of melatonin, new maxima appear 24 min following melatonin addition (arrow), an ENOX1 characteristic.

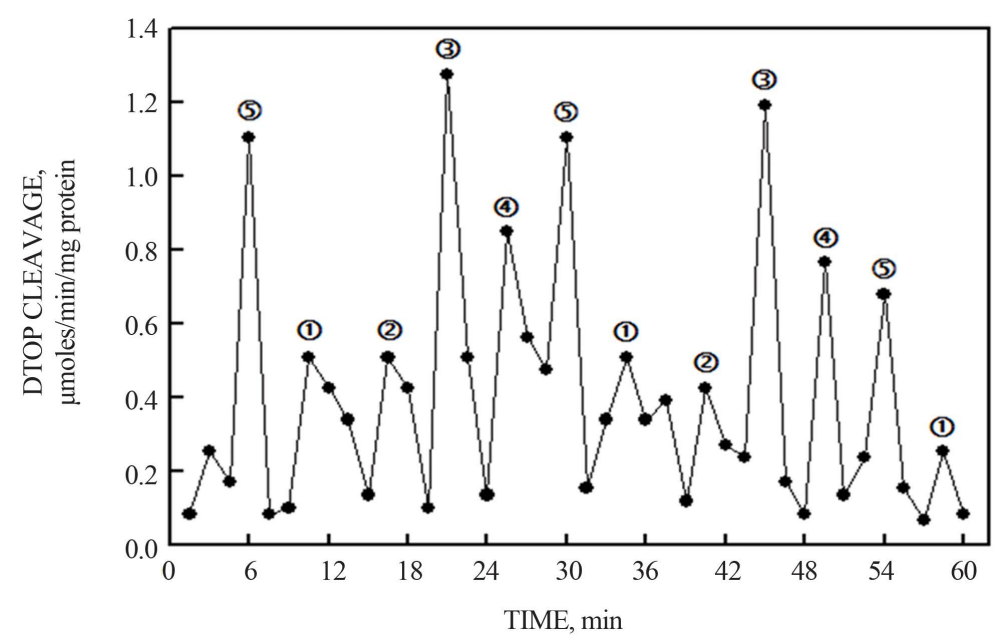

Figure 6. Protein disulfide-thiol interchange activity of IEF-purified recombinant Arabidopsis ENOX1 measured from the cleavage of a dithiodipyridine (DTDP) substrate. An oscillatory activity was observed with the activities were most strongly associated with the three maxima separated by $4.5 \mathrm{~min}$ rather than with the two maxima separated by $6 \mathrm{~min}$.

Primarily through reduction of the aggregation of the recombinant proteins, further purification by isoelectric focusing was required to achieve the reported specific activities. Highest specific activities were achieved at a focusing $\mathrm{pH}$ of about 6.9 (Figure 8) which approximates the calculated isoelectric point of the recombinant protein.

The ENOX activity eluted from the IEF gel was further identified as ENOX1 by its resistance to various ENOX2 inhibitors including cis-platinum, phenoxodiol, EGCg and capsaicin all tested at concentrations sufficient to inhibit ENOX2 activity completely (Table 1). Also, without effect, were tyrosol and gallic acid, specific inhibitors of arNOX (ENOX 3) and 2,4-dichlorophenoxyacetic acid (2,4-D) which serves as a specific activator of plant arNOX (ENOX 5) (Table 1). With the recombinant Arabidopsis ENOX1 protein eluted from the IEF gels, no inhibition was observed. Activity was inhibited by the ENOX1-specific quassinoid inhibitor simalika 




Figure 7. Ability of recombinant Arabidopsis ENOX1 to oxidize hydroquinone (reduced coenzyme $Q$ ) measured either by an increase in $A_{410}$ (upper) or a decrease in $\mathrm{A}_{290}$ (lower). As with NADH oxidation of Figure 3, the activity oscillates with prominent maxima separated by $6 \mathrm{~min}$, (1) and (2), to create a 24 min period containing 3 additional maxima separated by 4.5 min (total of 5 maxima).

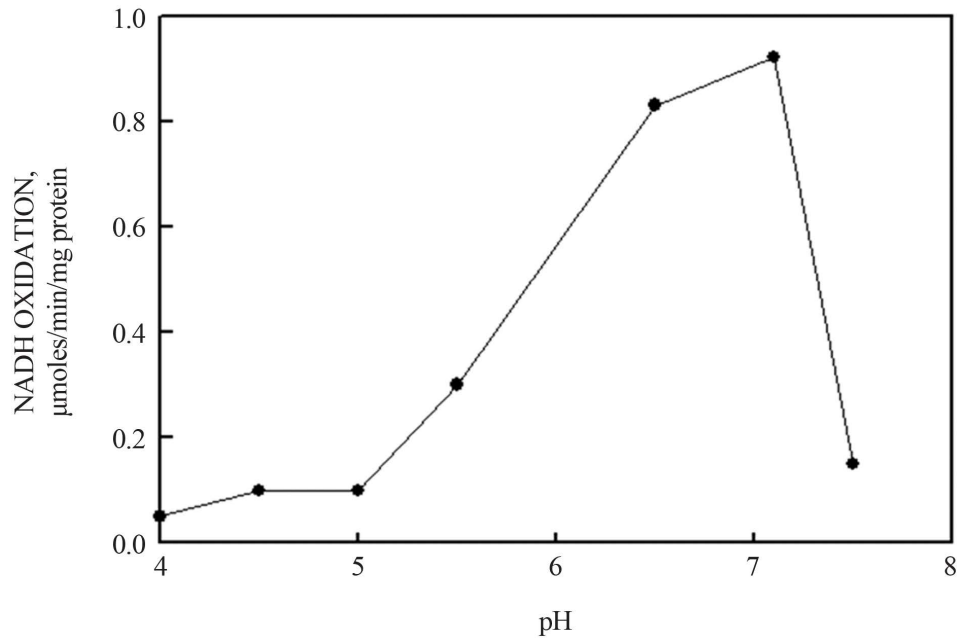

Figure 8. Purification and activation of recombinant Arabidopsis ENOX1 by isoelectric focusing.

lactone D (Figure 9) along with the growth regulating herbicides mefluidide and sulfosulfuron (Table 1). The 
Table 1. NADH oxidase activity of IEF-purified ENOX1 recombinant Arabidopsis and response to ENOX2 inhibitors, 2,4-D and the ENOX1 inhibitor simalikalactone D. Average of 3 determinations \pm standard deviations.

\begin{tabular}{cc} 
Inhibitor & $\begin{array}{c}\mu \text { moles/min/mg } \\
\text { protein }\end{array}$ \\
None & $3.7 \pm 0.4$ \\
Cis-platinum $(100 \mu \mathrm{M})$ & $3.5 \pm 0.02$ \\
Phenoxodiol $(10 \mu \mathrm{M})$ & $3.7 \pm 0.05$ \\
EGCg $(500 \mu \mathrm{M})$ & $3.9 \pm 0.05$ \\
Capsaicin $(1 \mu \mathrm{M})$ & $3.7 \pm 0.1$ \\
Tyrosol $(10 \mu \mathrm{M})$ & $3.4 \pm 0.2$ \\
Gallic acid $(100 \mu \mathrm{M})$ & $3.0 \pm 0.5$ \\
Simalikalactone D $(1 \mu \mathrm{M})$ & $0.9 \pm 0.1^{* *}$ \\
2,4-Dichlorophenoxyacetic acid $(1 \mu \mathrm{M})$ & $3.7 \pm 0.1$ \\
Mefluidide $(N$-[2,4-dimethyl-5-[(trifluoromethyl)sulfonyl]amino]phenyl]acetamide) & $1.8 \pm 0.15^{*}$ \\
Sulfosulfuron sulfonylurea herbicide $($ Trade Name: Outrider) $(100 \mu \mathrm{M})$ & $1.4 \pm 0.5^{*}$ \\
\hline
\end{tabular}

The concentration of cis-platinum, phenoxodiol, EGCg and capsaicin used results in $>90 \%$ inhibition of recombinant human ENOX2 assayed in parallel. The concentrations of tyrosol and gallic acid, specific inhibitors of arNOX (ENOX3), which, in separate experiments, resulted in $>90 \%$ inhibition of ENOX3 and 2,4-D at $1 \mu \mathrm{M}$, which specifically activates the dNOX of plants were without effect. Simalikalactone D is a general ENOX 1 inhibitor. ${ }^{*}$ Very significant $(\mathrm{p}=0.005-0.0034) .{ }^{* *}$ Extremely significant $\left.\mathrm{p}=0.0003\right)$.



Figure 9. Inhibition of recombinant Arabidopsis ENOX1 by the specific ENOX1 quassinoid inhibitor simalikalactone D.

auxin herbicide 2,4-dichlorophenoxyacetic acid (2,4-D) which stimulates the dNOX (=ENOX5) activity of soybean plasma membranes approximately two-fold at $1 \mu \mathrm{M}$, was without effect (Table 1).

\subsection{ENOX1 Activity Requires the Presence of Copper}

Copper presence was necessary for ENOX1 activity (Figure 10). The IEF-purified ENOX1 when unfolded in the presence of trifluoroacetic acid retained activity after dialysis and at physiological $\mathrm{pH}$. However, if the 


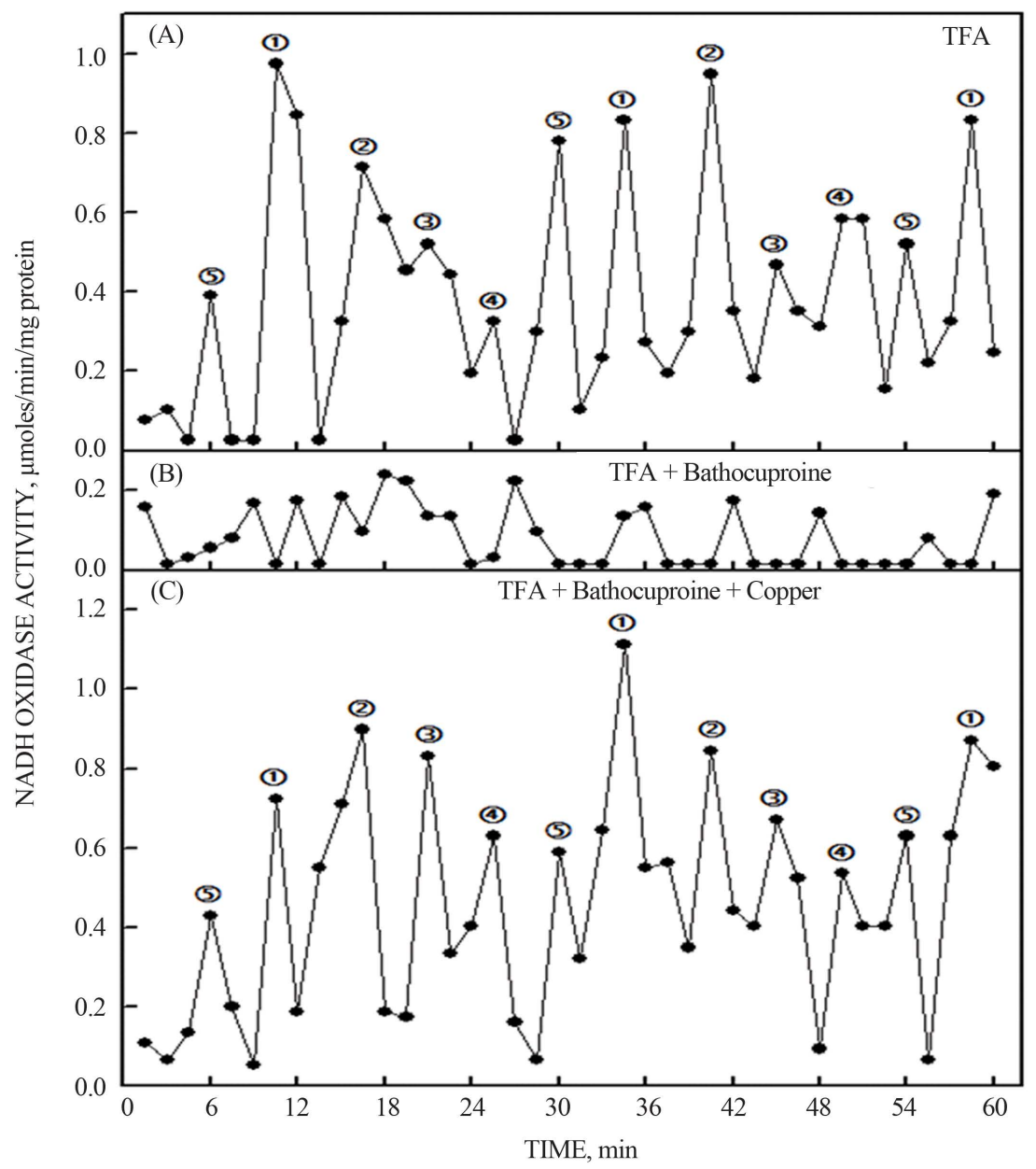

Figure 10. NADH oxidase activity of recombinant Arabidopsis ENOX1 diminished with TFA + bathocuproine. (A) In the presence of TFA, the 24 min period was unaffected; (B) When assayed with TFA and bathocuproine, the 24 min period was much reduced; (C) Removal of bathocuproine by dialysis and readdition of copper restored full activity.

ENOX1 was unfolded with trifluoroacetic acid in the presence of the copper chelator bathocuproine, activity was lost (Figure 10(B)). Activity was subsequently restored by refolding in the presence of copper at physiological pH (Figure 10(C)).

\subsection{Period Length in Deuterium Oxide}

ENOX1 activity when assayed in heavy water yielded a pattern of activities with the period length increased from 24 min to about 30 min (Figure 11).

\subsection{Site-Directed Mutagenesis}

Confirmation of functional assignments of motifs common to ENOX1 protein in general is provided for the specific functional motifs of the Arabidopsis ENOX1 by site-directed mutagenesis (Table 2). The G570A replacement in the putative adenine nucleotide binding motif largely eliminated NADH oxidation and reduced protein disulfide-thiol interchange by $75 \%$. Reduced activities were seen with both C463A and C534A replacements. A response to the C463A replacement was especially evident with protein disulfide-thiol interchange. Putative copper site replacements, Y468A and Y531A reduced activities as well. Activities were reduced to near background levels with the Y531A replacement. 


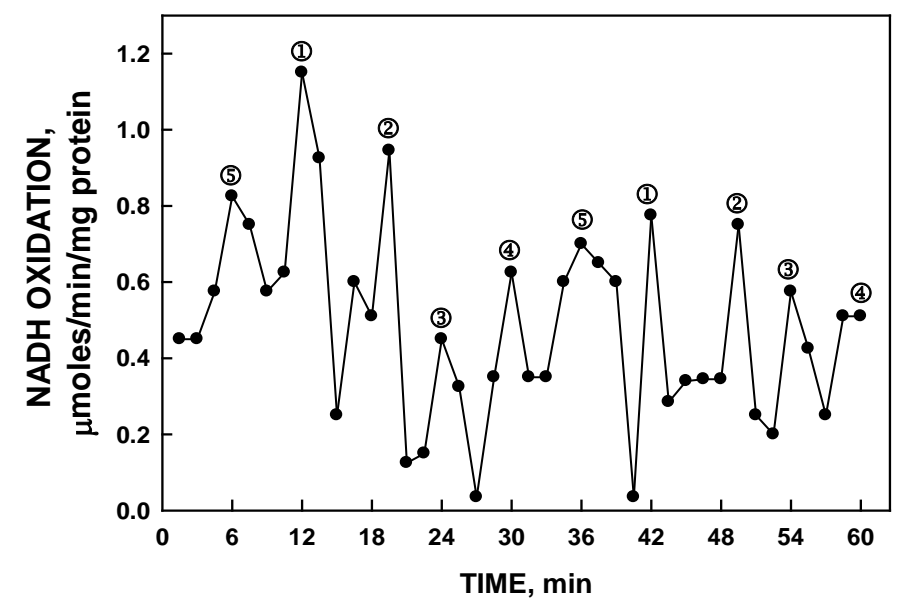

Figure 11. NADH oxidase activity of Arabidopsis ENOX1 when assayed in $\mathrm{D}_{2} \mathrm{O}$ exhibited an increase in period length from 24 min to 30 min. The effect of heavy water to increase period length is one of the hallmarks of the biological clock.

Table 2. Confirmation of functional motifs of Arabidopsis ENOX1 by site-directed mutagenesis. Average of 3 determinations \pm standard deviations.

\begin{tabular}{ccc}
\hline \multirow{2}{*}{ Mutation } & NADH oxidation & \multicolumn{2}{c}{ Disulfide-thiol interchange } \\
\cline { 2 - 3 } Wild type & \multicolumn{2}{c}{$\mu$ moles/min/mg protein } \\
G570A & $0.09 \pm 0.04$ & $1.00 \pm 0.16$ \\
C463A & $0.12 \pm 0.06^{* *}$ & $0.25 \pm 0.02^{*}$ \\
C534A & $0.33 \pm 0.07^{* *}$ & $0.01 \pm 0.01^{* *}$ \\
Y468A & $0.18 \pm 0.05^{* *}$ & $0.19 \pm 0.06^{* *}$ \\
Y479A & $0.80 \pm 0.01$ & $0.25 \pm 0.02^{*}$ \\
Y531A & $0.02 \pm 0.01^{* *}$ & $0.95 \pm 0.16$ \\
\hline
\end{tabular}

*Very significant $(\mathrm{p}=0.001-0.005),{ }^{* *}$ Extremely significant $(\mathrm{p}=0.0001-0.0004)$.

\section{Discussion}

The sequence of the putative plant ENOX1 protein appeared to be highly similar to that of ENOX1 of the yeast Saccharomyces cerevisiae [27]. Except for putative functional motifs, no similarity of the plant ENOX1 was found for human ENOX2 [6] or ENOX1 [4] or the yeast ENOX1. A putative NADH-binding site, a disulfidethiol interchange site, and copper-binding sites of both the plant and yeast ENOX1, were also found in the human ENOX1 and ENOX2 proteins while the putative anti-cancer drug binding site of ENOX2 was not.

Based on the high level of its similarity to ENOX1 of yeast, the $14 \mathrm{kDa}$ constitutive ECTO-NOX protein of plants is designated as an ENOX1 (see Hugo Gene Nomenclature Committee Designation http://www.gene.ucl.ac.uk/nomenclature/ for ENOX terminology). The cloned protein expressed in $E$. coli is listed as NCBI Accession No. BK008839.

When expressed in bacteria, the plant ENOX1 from Arabidopsis lyrata exhibited activity characteristics similar to those of ENOX1 proteins from mammalian [1] [15] [32] or other plant [1] [33]-[35] sources. Activity measured either as NADH oxidation (artificial substrate) or oxidation of reduced coenzyme Q (native substrate) oscillated with 5 activity maxima within each 24 min period. Period length was determined from two major activity maxima separated by 6 min and indicated by as (1) and (2) in the figures. Other maxima were separated from each other and from the two major activity maxima by intervals of $4.5 \mathrm{~min}(6 \mathrm{~min}+4 \times 4.5 \mathrm{~min}=24 \mathrm{~min})$. 
The 24 min period length is distinct from the 22 min period length of mammalian ENOX2 [6] [26] and the 26 min period length of mammalian, plant, or yeast arNOX [16]-[18].

The period of ENOX1 is phased by addition of melatonin as has been reported for ENOX1 proteins from other sources [36]. Upon addition of melatonin, a new period occurs exactly 24 min after melatonin addition and continues with the newly established period thereafter. This is a characteristic not shared either with ENOX2 or arNOX (ENOX3). Additionally, the Arabidopsis ENOX1 was unaffected by the ENOX3 inhibitors tyrosol and gallic acid or by the activator of the plant ENOX5, 2,4-D (Table 1). Also identifying the Arabidopsis protein as an ENOX1 protein is its inability to be inhibited by the ENOX2 inhibitor capsaicin and other ENOX2 inhibitors including EGCg, phenoxodiol and cis-platinum. This is consistent with the absence from its amino acid sequence of the putative drug binding site of ENOX2 [6].

We are unable to exclude the possibility that additional ENOX1 proteins may be discovered from plants with sequences different from the ENOX1 reported here. Thus far, proteins from a number of plant sources have been purified to homogeneity but have failed to yield $\mathrm{N}$-terminal amino acid sequence due to being blocked to $\mathrm{N}$-terminal sequencing and being resistant to proteolytic degradation including proteinase $\mathrm{K}$ proteolysis. Like ENOX2 [37] [38], the ENOX1 proteins share characteristics in common with prions [39] [40], Alzheimer's A $\beta$ protein [41], and aggregated tNOX proteins [42] especially those properties of resistance to protease degration and the ability to aggregate. The aggregated preparations of ENOX1 lacked enzymatic activity and were refractory to resolubilization. Size exclusion chromatography revealed approximately $10 \%$ dimers, $<2.5 \%$ monomers and low molecular weight fragments with the remainder consisting of aggregates in the range of 250,000 to $>1,000,000 \mathrm{kDa}$. The Arabidopsis ENOX1 amyloid, while insoluble even in SDS was completely disaggregated by boiling in SDS not unlike amyloid- $\beta$ [1]-[42] for example [43]. For reasons possibly related to dimerization rather than multimerization, ENOX1 proteins prepared by isoelectric focusing or eluted from isoelectric focusing gels did not aggregate, retained enzymatic activity and were stable in solution for several weeks or months when stored frozen or at $4^{\circ} \mathrm{C}$.

An important consideration from the studies reported here is that the human ENOX1 protein bound approximately 2 moles of copper/mole of protein [4]. As the prevailing soluble form of ENOX proteins may be dimers based on size exclusion chromatography, the presence of two coppers per monomer permits the ENOX1 to be viewed as a dimeric protein containing 4 coppers/dimer that is capable of carrying out 4 electron transfers from $\mathrm{NADH}$ or reduced coenzyme Q directly to molecular oxygen as required to form water. ENOX1 proteins do reduce molecular oxygen to water [44] despite the fact that they lack flavin and/or electron carriers other than copper [6].

This protein disulfide isomerase-like activity measured either as restoration of activity to denatured and inactive ribonuclease A or by cleavage of dithiodipyridine (DTDP) substrate as in the present study, also exhibits the oscillatory activity patterns characteristic of ENOX proteins in general [4]. For ENOX1, the period length is again 24 min due to the asymmetry imparted by two of the 5 maxima per period being separated by 6 min rather than the usual $4.5 \mathrm{~min}$. The protein disulfide-thiol interchange activity of the ENOX protein has been implicated as obligatory to the cell enlargement phase of cell growth for both animal [19] and plant [20] [21] cells. However, the mechanism whereby disulfide bonds are formed and broken through the action of NOX proteins may differ substantially from that of the classical flavoprotein disulfide isomerases. The portion of the Arabidopsis ENOX1 protein involved in protein disulfide-thiol interchange is unknown. A marked loss of activity resulted from both the C463A and the C534A replacements (Table 2). A source of protons and electrons is not required for the interchange activity as exemplified by the ability of ENOX1 alone to catalyze the restoration of activity to inactive and denatured ribonuclease A. Neither glutathione nor dithiothreitol support the protein disulfide-thiol interchange activity.

The high capacity of proliferating mammalian cells to transfer electrons from cytosolic NADH to extracellular acceptors like oxygen via plasma membrane electron transport [45] [46] is now generally regarded as being via a plasma membrane electron transport chain involving reduced quinones as the transmembrane carrier of electrons and protons [3] [47] [48]. The identification and cloning of the constitutive ENOX1 protein of plants whose proposed function is as a terminal oxidase for the plasma membrane electron transport chain [47] rather than superoxide generation, and as a driver of both cell enlargement and of the biological clock represents an important advance in our understanding of these enzyme proteins of the plasma membrane which have, until recently, been largely ill defined [48]. 


\section{Conclusion}

A gene encoding a candidate constitutive ECTO-NADH oxidase (ENOX1) was identified based on significant sequence homology with ENOX1 of Saccharomyces cerevisiae. Functional motifs conserved with human ENOX1 were identified by site directed mutagenesis. The Arabidopsis ENOX1 has catalytic properties of previously characterized ENOX proteins, requires bound copper for activity and exhibits time-keeping activity oscillations with a 24-min period phased by melatonin. As the prevailing soluble form is that of a dimer, the Arabidopsis ENOX1 emerges as dimeric protein containing 4 copper atoms per dimer capable of 4 electron transfers from NADH or reduced coenzyme Q directly to molecular oxygen to form water.

\section{Acknowledgements}

We thank Aya Ryuzoji for preparation of the figures, Peggy Runck for manuscript preparation and Ping Gao for assistance with site-directed mutagenesis.

\section{Nucleotide Sequence Data}

Nucleotide sequence data are available in The Third Party Annotation Section of the DOB/EMBL/GenBank databases under the accession number TPA: BK008839.

\section{References}

[1] Morré, D.J. (1998) NADH Oxidase: A Multifunctional Ectoproteins of the Eukaryotic Cell Surface. In: Asard, H., Bérczi, A. and Caubergs, R., Eds., Plasma Membrane Redox Systems and Their Role in Biological Stress and Disease, Kluwer Academic Publishers, Dordrecht, 121-156. http://dx.doi.org/10.1007/978-94-017-2695-5_5

[2] Morré, D.J. and Morré, D.M. (2003) Cell Surface NADH Oxidases (ECTO-NOX Proteins) with Roles in Cancer, Cellular Time-Keeping, Growth, Aging and Neurodegenerative Disease. Free Radical Research, 37, 795-808. http://dx.doi.org/10.1080/1071576031000083107

[3] Morré, D.J. and Morré, D.M. (2013) ECTO-NOX Proteins. Springer, New York, 507 p. http://dx.doi.org/10.1007/978-1-4614-3958-5

[4] Jiang, Z., Gorenstein, N.M., Morré, D.M. and Morré, D.J. (2008) Molecular Cloning and Characterization of a Candidate Human Growth-Related and Time-Keeping Constitutive Cell Surface Hydroquinone (NADH) Oxidase. Biochemistry, 47, 14028-14038. http://dx.doi.org/10.1021/bi801073p

[5] Chueh, P.-J., Morré, D.J., Wilkinson, F.E., Gibson, J. and Morré, D.M. (1997) A 33.5 kDa Heat- and Protease-Resistant NADH Oxidase Inhibited by Capsaicin from Sera of Cancer Patients. Archives of Biochemistry and Biophysics, 342, 38-47. http://dx.doi.org/10.1006/abbi.1997.9992

[6] Chueh, P.-J., Kim, C., Cho, N., Morré, D.M. and Morré, D.J. (2002) Molecular Cloning and Characterization of a Tumor-Associated, Growth-Related and Time-Keeping Hydroquinone (NADH) Oxidase (NOX) of the HeLa Cell Surface. Biochemistry, 41, 3732-3741. http://dx.doi.org/10.1021/bi012041t

[7] Morré, D.J., Chueh, P.-J. and Morré, D.M. (1995) Capsaicin Inhibits Preferentially the NADH Oxidase and Growth of Transformed Cells in Culture. Proceedings of the National Academy of Sciences USA, 92, 1831-1835. http://dx.doi.org/10.1073/pnas.92.6.1831

[8] Morré, D.J., Sun, E., Geilen, C., Wu, L.-Y., De Cabo, R., Krasagakis, K., Orfanos, C.E. and Morré, D.M. (1996) Capsaicin Inhibits Plasma Membrane NADH Oxidase and Growth of Human and Mouse Melanoma Lines. European Journal of Cancer, 32A, 1995-2003. http://dx.doi.org/10.1016/0959-8049(96)00234-1

[9] Morré, D.J., Wu, L.-Y. and Morré, D.M. (1995) The Antitumor Sulfonylurea N-(4-methylphenylsulfonyl)-N(-(chlorophenyl)urea (LY181984) Inhibits NADH Oxidase Activity of HeLa Plasma Membranes. Biochimica et Biophysica Acta, 1240, 11-17. http://dx.doi.org/10.1016/0005-2736(95)00164-7

[10] Morré, D.J., Wilkinson, F.E., Kim, C., Cho, N., Lawrence, J., Morré, D.M. and McClure, D. (1996) Antitumor Sulfonylurea-Inhibited NADH Oxidase of Cultured HeLa Cells Shed into Media. Biochimica et Biophysica Acta, 1280, 197206. http://dx.doi.org/10.1016/0005-2736(95)00290-1

[11] Morré, D.J., Chueh, P.-J., Yagiz, K., Balicki, A., Kim, C. and Morré, D.M. (2007) ECTO-NOX Target for the Anticancer Isoflavene Phenoxodiol. Oncology Research, 16, 299-312.

[12] Morré, D.J., Grieco, P.A. and Morré, D.M. (1998) Mode of Action of the Anticancer Quassinoids-Inhibition of the Plasma Membrane NADH Oxidase. Life Science, 63, 595-604. http://dx.doi.org/10.1016/S0024-3205(98)00310-5

[13] Morré, D.J. and Greico, P.A. (1999) Glaucarubolone and Simalikalactone D, Respectively, Preferentially Inhibit Aux- 
in-Induced and Constitutive Components of Plant Cell Enlargement and the Plasma Membrane NADH Oxidase. International Journal of Plant Sciences, 160, 291-297. http://dx.doi.org/10.1086/314133

[14] Wilkinson, F.E., Kim, C., Cho, N., Chueh, P.-J., Leslie, S., Moya-Camarena, S., Wu, L.-Y., Morré, D.M. and Morré, D.J. (1996) Isolation and Identification of a Protein with Capsaicin-Inhibited NADH Oxidase Activity from Culture Media Conditioned by Growth of HeLa Cells. Archives of Biochemistry and Biophysics, 336, 275-282. http://dx.doi.org/10.1006/abbi.1996.0558

[15] Sedlak, D., Morré, D.M. and Morré, D.J. (2001) A Drug-Unresponsive and Protease-Resistant CNOX Protein from Human Sera. Archives of Biochemistry and Biophysics, 386, 106-116. http://dx.doi.org/10.1006/abbi.2000.2180

[16] Morré, D.M. and Morré, D.J. (2003) Specificity of Coenzyme Q Inhibition of an Aging-Related Cell Surface NADH Oxidase (ECTO-NOX) That Generates Superoxide. BioFactors, 18, 33-43. http://dx.doi.org/10.1002/biof.5520180205

[17] Dick, S., Phung, C., Morré, D.M. and Morré, D.J. (2013) Molecular Cloning and Characterization of an ECTO-NOX3 (ENOX3) of Saccharomyces cerevisiae. Advances in Biological Chemistry, 3, 505-511. http://dx.doi.org/10.4236/abc.2013.35055

[18] Morré, D.M., Guo, F. and Morré, D.J. (2003) An Aging-Related Cell Surface NADH Oxidase (arNOX) Generates Superoxide and Is Inhibited by Coenzyme Q. Molecular and Cellular Biochemistry, 254, 101-109. http://dx.doi.org/10.1023/A:1027301405614

[19] Pogue, R., Morré, D.M. and Morré, D.J. (2000) CHO Cell Enlargement Oscillates with a Temperature-Compensated Period of 24 Minutes. Biochimica et Biophysica Acta, 1498, 44-51. http://dx.doi.org/10.1016/S0167-4889(00)00076-8

[20] Morré, D.J., Pogue, R. and Morré, D.M. (2001) Soybean Cell Enlargement Oscillates with a Temperature-Compensated Period Length of ca. 24 Min. In Vitro Cellular \& Developmental Biology-Plant, 37, 19-23. http://dx.doi.org/10.1007/s11627-001-0004-3

[21] Morré, D.J., Ternes, P. and Morré, D.M. (2002) Cell Enlargement of Plant Tissue Explants Oscillates with a Temperature-Compensated Period Length of ca. 24 Min. In Vitro Cellular \& Developmental Biology-Plant, 38, 18-28. http://dx.doi.org/10.1079/IVP2001249

[22] Morré, D.J., Brightman, A.O., Hidalgo, A. and Navas, P. (1995) Selective Inhibition of Auxin-Stimulated NADH Oxidase Activity and Elongation Growth of Soybean Hypocotyls by Thiol Reagents. Plant Physiology, 107, 1285-1291.

[23] Kishi, T., Morré, D.M. and Morré, D.J. (1999) The Plasma Membrane NADH Oxidase of HeLa Cells Has Hydroquinone Oxidase Activity. Biochimica et Biophysica Acta, 1412, 66-77. http://dx.doi.org/10.1016/S0005-2728(99)00049-3

[24] Morré, D.J., De Cabo, R., Jacobs, E. and Morré, D.M. (1995) Auxin-Modulated Protein Disulfide-Thiol Interchange Activity from Soybean Plasma Membranes. Plant Physiology, 109, 573-578.

[25] Morré, D.J., Gomez-Rey, M.L., Schramke, C., Em, O., Lawler, J., Hobeck, J. and Morré, D.M. (1999) Use of Dipyridyl-Dithio Substrates to Measure Directly the Protein Disulfide-Thiol Interchange Activity of the Auxin Stimulated NADH: Protein Disulfide Reductase (NADH Oxidase) of Soybean Plasma Membranes. Molecular and Cellular Biochemistry, 200, 7-13. http://dx.doi.org/10.1023/A:1006916116297

[26] Morré, D.J., Chueh, P.-J., Pletcher, J., Tang, X.Y., Wu, L.-Y. and Morré, D.M. (2002) Biochemical Basis for the Biological Clock. Biochemistry, 41, 11941-11945. http://dx.doi.org/10.1021/bi020392h

[27] Chueh, P.-J., Morré, D.M. and Morré, D.J. (2002) A Site-Directed Mutagenesis Analysis of tNOX Functional Domains. Biochimica et Biophysica Acta, 1594, 74-83. http://dx.doi.org/10.1016/S0167-4838(01)00286-2

[28] Altschul, S.F., Madden, T.L., Schäffer, A.A., Zhang, J., Zhang, Z., Miller, W. and Lipman, D.J. (1997) Gapped BLAST and PSI-BLAST: A New Generation of Protein Database Search Programs. Nucleic Acids Research, 25, 3389-3402. http://dx.doi.org/10.1093/nar/25.17.3389

[29] Dick, S.S., Ryuzoji, A., Morré, D.M. and Morré, D.J. (2013) Identification of the Constitutive Ultradian Oscillator of the Circadian Clock (ENOX1) in Saccharomyces cerevisiae. Advances in Biological Chemistry, 3, 320-328. http://dx.doi.org/10.4236/abc.2013.33036

[30] Smith, P.K., Krohn, R.I., Hermanson, G.T., Mailia, A.K., Gartner, F.F., Provenzano, M.D., Fujimoto, E.K., Groeke, N.M., Olson, B.J. and Klenk, D.C. (1985) Measurement of Protein Using Bicinchoninic Acid. Analytical Biochemistry, 150, 76-85. http://dx.doi.org/10.1016/0003-2697(85)90442-7

[31] Braman, J., Papworth, C. and Greener, A. (1996) Site-Directed Mutagenesis Using Double-Stranded Plasmid DNA Templates. Methods Molecular Biology, 57, 31-44.

[32] Brightman, A.O., Wang, J., Miu, R.K., Sun, I.L., Barr, R., Crane, F.L. and Morré, D.J. (1992) A Growth Factor- and Hormone-Stimulated NADH Oxidase from Rat Liver Plasma Membrane. Biochimica et Biophysica Acta, 1105, 109117. http://dx.doi.org/10.1016/0005-2736(92)90168-L

[33] Morré, D.J. and Brightman, A.O. (1991) NADH Oxidase of Plasma Membranes. Journal of Bioenergetics and Biomembranes, 23, 469-489. http://dx.doi.org/10.1007/BF00771015 
[34] Brightman, A.O., Barr, R., Crane, F.L. and Morré, D.J. (1988) Auxin-Stimulated NADH Oxidase Purified from Plasma Membrane of Soybean. Plant Physiology, 86, 1264-1269. http://dx.doi.org/10.1104/pp.86.4.1264

[35] Morré, D.J. and Morré, D.M. (1998) NADH Oxidase Activity of Soybean Plasma Membrane Oscillates with a Temperature Compensated Period of 24 Min. The Plant Journal, 16, 279-284. http://dx.doi.org/10.1046/j.1365-313x.1998.00293.x

[36] Morré, D.J., Penel, C., Greppin, H. and Morré, D.M. (2002) The Plasma Membrane-Associated NADH Oxidase of Spinach Leaves Responds to Blue Light. International Journal of Plant Sciences, 613, 543-547. http://dx.doi.org/10.1086/340543

[37] Kelker, M., Kim, C., Chueh, P.J., Guimont, R., Morré, D.M. and Morré, D.J. (2001) Cancer Isoform of a Tumor-Associated Cell Surface NADH Oxidase (tNOX) Has Properties of a Prion. Biochemistry, 40, 7351-7354. http://dx.doi.org/10.1021/bi010596i

[38] Kim, C. and Morré, D.J. (2004) Prion Proteins and ECTO-NOX Proteins Exhibit Similar Oscillating Redox Activities. Biochemical and Biophysical Research Communications, 315, 1140-1146. http://dx.doi.org/10.1016/j.bbrc.2004.02.007

[39] Griffith, J.S. (1964) Self-Replication and Scrapie. Nature, 315, 1043-1044.

[40] Prusiner, S.B. (1994) Biology and Genetics of Prion Diseases. Annual Review of Microbiology, 48, 655-686. http://dx.doi.org/10.1146/annurev.mi.48.100194.003255

[41] Multhaup, G. (1997) Amyloid Precursor Protein, Copper and Alzheimer's Disease. Biomedicine \& Pharmacotherapy, 51, 105-111. http://dx.doi.org/10.1016/S0753-3322(97)86907-7

[42] del Castillo-Olivares, A., Yantiri, F., Chueh, P.-J., Wang, S., Sweeting, M., Sedlak, D., Morré, D.M., Burgess, J. and Morré, D.J. (1998) A Drug-Responsive and Protease-Resistant Peripheral NADH Oxidase Complex from the Surface of HeLa S Cells. Archives of Biochemistry and Biophysics, 358, 125-140. http://dx.doi.org/10.1006/abbi.1998.0823

[43] Rangachari, V., Morré, B.D., Reed, D.K., Sonoda, L.K., Bridges, A.W., Conboy, E., Hartigan, D. and Rosenberry, T.L. (2007) Amyloid- $\beta$ (1-42) Rapidly Forms Protofibrils and Oligomers by Distinct Pathways in Low Concentrations of Sodium Dodecylsulfate. Biochemistry, 46, 12451-12462. http://dx.doi.org/10.1021/bi701213s

[44] Orczyk, J., Morré, D.M. and Morré, D.J. (2005) Periodic Fluctuations in Oxygen Consumption Comparing HeLa (Cancer) and CHO (Non-Cancer) Cells and Response to External NAD(P) ${ }^{+} / \mathrm{NAD}(\mathrm{P}) \mathrm{H}$. Molecular and Cellular Biochemistry, 273, 161-167. http://dx.doi.org/10.1007/s11010-005-0326-2

[45] Berridge, M.V. and Tan, A.S. (2000) High-Capacity Redox Control at the Plasma Membrane of Mammalian Cells: Trans-Membrane, Cell Surface, and Serum NADH-Oxidases. Antioxidants \& Redox Signaling, 2, 231-242. http://dx.doi.org/10.1089/ars.2000.2.2-231

[46] Hyun, D.-H., Hunt, N.D., Emerson, S.S., Hernandez, J.O., Mattson, M.P. and de Cabo, R. (2007) Up-Regulation of Plasma Membrane-Associated Redox Activities in Neuronal Cells Lacking Functional Mitochondria. Journal of Neurochemistry, 100, 1364-1374. http://dx.doi.org/10.1111/j.1471-4159.2006.04411.x

[47] Crane, F.L. and Low, H. (2008) Reactive Oxygen Species Generation at the Plasma Membrane for Antibody Control. Autoimmunity Reviews, 7, 518-522. http://dx.doi.org/10.1016/j.autrev.2008.04.004

[48] Baker, M.A. and Lawen, A. (2000) Plasma Membrane NADH-Oxidoreductase System: A Critical Review of the Structural and Functional Data. Antioxidants \& Redox Signaling, 2, 197-212.

http://dx.doi.org/10.1089/ars.2000.2.2-197

\section{Abbreviations}

arNOX, age-related cell surface NADH oxidase = ENOX; CNOX, constitutive and drug-unresponsive cell surface NADH oxidase (ENOX1); DTDP, dithiodipyridine dNOX, 2,4-D (auxin-activated cel surface NADH oxidase (ENOX5); ENOX, ECTO-NOX; tNOX, tumor (cancer)-associated and drug-(capsaicin) inhibited cell surface NADH oxidase (ENOX2); IEF, isoelectric focusing; PMSF, $\rho$-chloromercurisuifunic acid; SDS-PAGE, sodium dodecylsulfate polyacrylamide gel electrophoresis; TFA, tritluroacetic acid; tNOX, tumor (cancer)-associated and drug (capsaicin) inhibited cell surface NADH oxidase (ENOX2). 
Scientific Research Publishing (SCIRP) is one of the largest Open Access journal publishers. It is currently publishing more than 200 open access, online, peer-reviewed journals covering a wide range of academic disciplines. SCIRP serves the worldwide academic communities and contributes to the progress and application of science with its publication.

Other selected journals from SCIRP are listed as below. Submit your manuscript to us via either submit@scirp.org or Online Submission Portal.

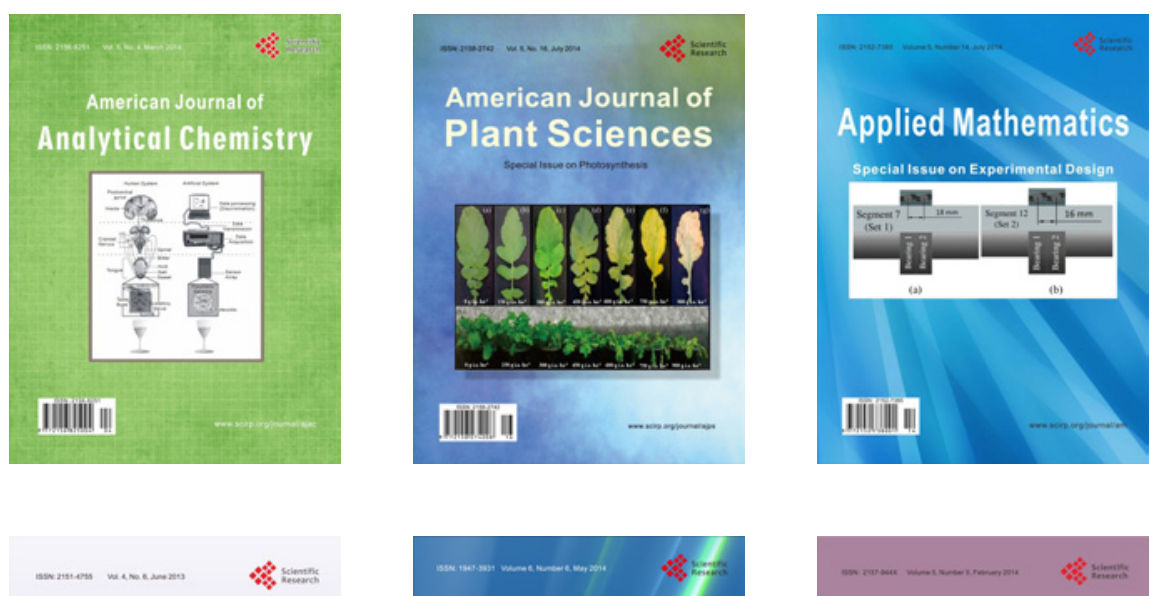

Creative Education
